\title{
Correction to: Population health management in France: specifying population groups through the DRG system
}

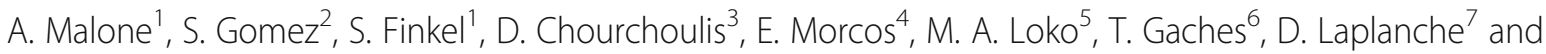 \\ S. Sanchez $z^{7,8^{*}}$
}

\section{Correction to: BMC Health Serv Res 21, 733 (2021) https://doi.org/10.1186/s12913-021-06757-x}

Following publication of the original article [1], the affiliation numbers for the author D. Laplanche were incorrect, and should be changed from D. Laplanche ${ }^{7,8}$ to D. Laplanche ${ }^{7}$.

The author affiliation list has been updated above and the original article [1] has been corrected.

\begin{abstract}
Author details
${ }^{1}$ French Hospital Federation, Paris, France. ${ }^{2}$ Departement d'Information Médicale, CHU Clermont-Ferrand, Clermont-Ferrand, France. ${ }^{3}$ Département d'Information Médicale, Centre Hospitalier de Douai, Douai, France.

${ }^{4}$ Département d'Information Médicale, Centre Hospitalier de Vesoul, Vesoul, France. ${ }^{5}$ Département d'Information Médicale, Centre Hospitalier de Dax, Dax, France. ${ }^{6}$ Département d'Information Médicale, Centre Hospitalier de Chartres, Chartres, France. ${ }^{7}$ Pôle Territorial Santé Publique et Performance, Hopitaux Champagne Sud, Troyes, France. ${ }^{8}$ Universitary comity of ressources for research in health (CURRS) University of Reims Champagne-Ardenne, 51 Rue Cognacq Jay, 51095 Reims Cedex, France.
\end{abstract}

Published online: 09 August 2021

\section{Reference}

1. Malone, et al. Population health management in France: specifying population groups through the DRG system. BMC Health Serv Res. 2021;21: 733.

\footnotetext{
The original article can be found online at https://doi.org/10.1186/s12913021-06757-x

* Correspondence: stephane.sanchez@hcs-sante.fr

${ }^{7}$ Pôle Territorial Santé Publique et Performance, Hopitaux Champagne Sud, Troyes, France

${ }^{8}$ Universitary comity of ressources for research in health (CURRS) University of Reims Champagne-Ardenne, 51 Rue Cognacq Jay, 51095 Reims Cedex,

France

Full list of author information is available at the end of the article
}

(c) The Author(s). 2021 Open Access This article is licensed under a Creative Commons Attribution 4.0 International License, which permits use, sharing, adaptation, distribution and reproduction in any medium or format, as long as you give appropriate credit to the original author(s) and the source, provide a link to the Creative Commons licence, and indicate if changes were made. The images or other third party material in this article are included in the article's Creative Commons licence, unless indicated otherwise in a credit line to the material. If material is not included in the article's Creative Commons licence and your intended use is not permitted by statutory regulation or exceeds the permitted use, you will need to obtain permission directly from the copyright holder. To view a copy of this licence, visit http://creativecommons.org/licenses/by/4.0/. The Creative Commons Public Domain Dedication waiver (http://creativecommons.org/publicdomain/zero/1.0/) applies to the data made available in this article, unless otherwise stated in a credit line to the data. 